\title{
FEED PREFERENCES AND FEEDING BEHAVIOUR OF TWO SPECIES OF AFRICAN GIANT LAND SNAILS
}

\author{
PREFERENCIAS Y COMPORTAMIENTO ALIMENTARIO DE DOS ESPECIES DE \\ CARACOLES TERRESTRES GIGANTES AFRICANOS
}

\author{
Ogbu, C.C. ${ }^{1 *}$; Ani, A.O. ${ }^{2}$ and Emeh, M. ${ }^{2}$ \\ ${ }^{1}$ College of Veterinary Medicine. Michael Okpara University of Agriculture. Umudike. Nigeria. \\ *coschi07@yahoo.com \\ ${ }^{2}$ Department of Animal Science. University of Nigeria. Nsukka. Nigeria.

\section{Additional KeYWORDS} \\ A. achatina. A. marginata. Nocturnal activity.

\section{Palabras clave adicionales} \\ A. achatina. A. marginata. Actividad nocturna.
}

\section{SUMMARY}

The feed preferences and time of peak feeding behaviour in $A$. achatina and $A$. marginata snails were studied, measuring activity on several feedstuffs, hourly from 19:30 to 00:30 h daily. The study involved 120 juvenile snails (60/genotype) shared into three replicates of 20 snails each per genotype. Each replicate was housed in a cage measuring $30 \times 20 \times 24 \mathrm{~cm}$. The animals were provided 8 feed stuffs namely: layers mash (LM), ripped banana fruit (RBF) and peel (RBP), ripped pawpaw fruit (RPF), Telferia occidentalis (TO), poultry dropping $(P D)$, rumen digesta $(R D)$ and a diet containing $10 \%$ rumen digesta (RD10). Animals were fed only during the nocturnal period. Data were collected hourly from 19:30 to 00:30 h each day for 7 days. Results showed significant $(p<0.05)$ differences in the preference of the different feed stuffs by each snail species as well as species differences in feed preferences and time of peak feeding behaviour. The three most appetent feed stuffs were LM, RD10 and PD for $A$. achatina and LM, RPF and RD10 for $A$. marginata. Overall, feeding behaviour peaked between 22:30 and $23: 30 \mathrm{~h}$ in $A$. achatina and $20: 30$ and $21: 30 \mathrm{~h}$ in $A$. marginata. Snail species should therefore be fed on the most preferred feed stuffs and within the periods of peak feeding behaviour for optimal performance and to minimize wastage.

\section{RESUMEN}

El objetivo del estudio fue evaluar las preferencias y el tiempo de máxima actividad de alimen- tación en caracoles A. Achatina y A. marginata, midiendo la distribución horaria sobre los alimentos empleados de 19:30 a 00:30 horas. En el estudio participaron 120 caracoles juveniles (60/ genotipo) en tres repeticiones de 20 caracoles por cada genotipo. Cada réplica fue alojada en una jaula de $30 \times 20 \times 24 \mathrm{~cm}$. A los animales se les proporcionó los siguientes 8 alimentos: mezcla de ponedoras (LM), frutos maduros de banano (RBF) y sus pieles (RBP), frutos maduros de papaya (FPR), Telferia occidentalis (TO), excretas de aves de corral (PD), digesta ruminal (RD) dieta con $10 \%$ de digesta ruminal secada al sol (RD10). Los animales fueron alimentados sólo durante el periodo nocturno. Los datos fueron recolectados cada hora 19:30-00:30, cada día, durante 7 días. Los resultados mostraron diferencias $(p<0,05)$ en la preferencia de los alimentos entre las especies de caracoles, así como en sus preferencias de alimentación y el tiempo de máxima actividad. Los tres alimentos más preferidos fueron: LM, RPF y RD10 para $A$. marginata. La actividad de alimentación tuvo su máximo entre 22:30 y 23:30 para $A$. achatina y entre $20: 30$ y $21: 30$ para $A$. marginata. Por tanto, estas especies de caracoles deberían ser alimentadas con los alimentos preferidos y dentro de los períodos de máxima actividad para un rendimiento óptimo y mínimo desperdicio.

\section{INTRODUCTION}

All life must acquire organic and inorganic substances as fuel and raw ma- 
terials for energetic, metabolic and physiological processes (Scott et al., 2005). Most plants synthesize their food requirements using primary elements - carbon, oxygen and hydrogen in the presence of light. Animals on the other hand must acquire their nutrient requirements from their environment. In consequence, animals have evolved specialized behavioural patterns to detect, acquire and ingest food. Foodrelated behaviour includes all actions exhibited by an animal in response to hunger or the perception of food. Hunger is the primary internal stimulus that motivate the search for and acquisition of food (Gillete $e t$ al., 2000). External factors that influence food behaviour include abundance and distribution of food material, presence of competitors, risk of predators, season and time of day (Gillete et al., 2000; Scott et al., 2005). Feed preference determines the feed ingested by an animal which in turn affects its physiological condition and fitness (Scott et al., 2005). The concept of feed preference comprises two features of the feed, attractiveness (measured by choice tests) and palatability (measured by comparing the quantity of the different feed stuffs ingested). Albuquerque et al. (2008) used catch per unit effort to study the distribution, feeding behaviour (feed preference) and control strategies of Achatina fulica.

Achatina achatina and Achachatina marginata (Phylum: Mollusca; Class: Gastropoda; Family: Achatinidae) are terrestrial shell bearing snails common in the humid rainforest zones of southeastern and western Nigeria. The snails grow in the wild and are farmed for food. Snail meat is treated as a delicacy in Nigeria and command high market demand (Ugwu et al., 2011). The distribution of $A$. achatina and A. marginata snails in natural habitats is seasonal and the normal activities of the snails such as feeding and reproduction are regulated by seasonal factors and diurnal photoperiods (Albuquerque et al., 2008). The snails are mostly active at night and hide during the day (Ademolu et al., 2011). Snails are polyphagous (Chevalier et al., 2000). They feed on a variety of plant materials (leaves and fruits) as well as on decaying organic matter (Albuquerque et al., 2008; Ademolu et al., 2011). The versatile taste of land snails is an important adaptive feature in the wild however, for rapid growth and high returns in farmed species, adequate nutrition is very important. There are species specific nutrient requirements which cannot be met by a generalist approach and genetic differences between and within species in nutrient requirements are well documented (Carefoot and Switzer-Dunlap, 1989). Farmed snails will perform best if the most preferred feed materials are provided at the optimal period of feed intake. Field and On-farm feed preference studies (Iglesias and Castillejo, 1999; Chevalier et al., 2000; Chevalier et al., 2003; Ebenso and Adeyemo, 2011) have demonstrated the capacity of snails to choose their feed when given free choice feeding and to retain memories of preferred feeds. How animals develop feed preference is complex however, this has been linked to post ingestive effects (satiety or malaise) and their interaction with mainly the senses of taste and smell (Provenza, 1995; Kimberly and Salice, 2012). If a farmer knows the specific nutritional requirements of his snails and the peak period of nutrient intake, he will be equipped to plan for their feeding for optimal nutritional benefits. The present study was therefore aimed at evaluating the feed preferences and the time of peak feeding activity in A. achatina and A. marginata snails using commonly available feed stuffs and the distribution of snails to the feed stuffs at different nocturnal time periods. The results would assist snail farmers in the choice of feeding materials for each type of snail and the best time to feed their snails. 


\section{FEEDING BEHAVIOUR OF TWO AFRICAN GIANT LAND SNAILS}

\section{MATERIALS AND METHODS}

\section{LOCATION OF STUDY AND BIOLOGICAL MATERIALS}

The study was carried out in the Snailery Section of the Department of Animal Science, University of Nigeria, Nsukka. Juvenile snails aged 4 weeks (wk) belonging to two genotypes were used for the study. The snails were hatched from adults of the respective genotypes maintained for research purposes. From hatch the hatchlings were reared on a variety of feed materials (fruits and leaves, bread) and poultry mash. The plant materials included Ipomea batata, ripped pawpaw (Carica papaya) fruit and leaves, ripped banana fruit and peel, Hibiscus, Telferia occidentalis, cocoyam etc. From these materials were selected poultry mash (commercial layers mash, LM), ripped banana fruit (RBF) and peel (RBP), ripped pawpaw fruit (RPF), and Telferia occidentalis (TO) for the present study. To these were added oven dried poultry dropping (PD), rumen digesta (RD), and a diet containing $10 \%$ rumen digesta (RD10), as novel feed stuffs (table I). The rumen digesta was collected from the rumen of cows slaughtered at the local abattoir, sun dried to a consistent weight and stored for the experiment while the PD was from caged layers in the Departmental Farm.

\section{EXPERIMENTAL CONDITION AND DESIGN}

The details for the construction of the snailery had been described in Ogbu and Ugwu (2011). In summary it consists of an enclosure with wooden poles, expanded metal and chick wire mesh. A covering of creeping plants provide good shade and ample ventilation to the snailery. The mean ambient conditions of the habitat during the experiment were $26.2 \pm 1.4{ }^{\circ} \mathrm{C}$ (range: 23.8 $28.0^{\circ} \mathrm{C}$ ), $68 \%$ relative humidity (range: 56 $75 \%$ ), and $12 \mathrm{~h}$ light:dark cycle.

Wooden cages measuring $60 \times 40 \times 24 \mathrm{~cm}$ each were used for the experiment. The cages were demarcated into two compartments, each measuring $30 \times 20 \times 24 \mathrm{~cm}$. The floor of the cages was cover with $2 \mathrm{~cm}$ thick sterilized top soil while the legs of the cages were inserted in a container of diluted engine oil to prevent the attack of insects and other predators. One hundred and twenty (120) snails (60/genotype) were used for the study. Each genotype was randomly divided into three replicates of 20 snails each. Two replicates (one/genotype) were housed in a

Table I. Percent composition of RD10 diet and proximate composition of RD10 diet and RD. (Composición porcentual de la dieta RD10 y composición nutritiva de la dieta RD).

\begin{tabular}{|c|c|c|c|c|}
\hline Ingredient & Composition (\%) & Proximate composition & RD10 & $\mathrm{RD}$ \\
\hline Maize & 52.00 & Energy (MJ) & 13.87 & 12.04 \\
\hline Soy bean meal & 25.00 & Crude protein (\%) & 20.96 & 14.45 \\
\hline Wheat bran & 5.00 & Crude fibre (\%) & 19.60 & 47.50 \\
\hline Rumen digesta & 10.00 & Ash (\%) & 13.40 & 25.20 \\
\hline Fish meal & 2.00 & Fat $(\%)$ & 2.30 & 0.30 \\
\hline Bone meal & 5.75 & NFE (\%) & 32.94 & 6.15 \\
\hline Mineral premix & 0.25 & & & \\
\hline Total & 100.00 & & & \\
\hline \multicolumn{5}{|c|}{ Calculated composition } \\
\hline Crude protein (\%) & 19.04 & & & \\
\hline Energy (kcal/kg) & 2858.62 & & & \\
\hline
\end{tabular}

$\mathrm{RD} 10=10 \%$ rumen digesta diet; RD= rumen digesta. 


\section{OGBU, ANI AND EMEH}

Table II. Distribution offeeding snails (sum for 7 days) according to genotype, feedstuff and time period ( $h$ ). (Distribución horaria de la actividad alimenticia de los caracoles (suma de 7 días) según genotipo, alimento y periodo del día).

\begin{tabular}{lcccccccccccc}
\hline Feedstuff & \multicolumn{2}{c}{$19: 30$} & \multicolumn{2}{c}{$20: 30$} & \multicolumn{2}{c}{$21: 30$} & \multicolumn{2}{c}{$22: 30$} & \multicolumn{2}{c}{$23: 30$} & \multicolumn{2}{c}{$00: 30$} \\
& A A & AM & A A & AM & A A & AM & AA & AM & AA & AM & AA & AM \\
\hline PD & 9 & 10 & 43 & 26 & 32 & 24 & 45 & 17 & 26 & 25 & 27 & 14 \\
RPF & 0 & 24 & 7 & 77 & 6 & 90 & 7 & 66 & 14 & 48 & 6 & 30 \\
RBP & 1 & 12 & 12 & 26 & 6 & 30 & 9 & 31 & 18 & 19 & 9 & 15 \\
RBF & 1 & 39 & 12 & 55 & 7 & 55 & 12 & 38 & 17 & 45 & 3 & 18 \\
TO & 5 & 20 & 16 & 53 & 14 & 38 & 26 & 41 & 37 & 39 & 28 & 35 \\
LM & 6 & 26 & 34 & 72 & 29 & 105 & 43 & 71 & 32 & 67 & 30 & 40 \\
RD10 & 4 & 18 & 13 & 58 & 26 & 61 & 38 & 54 & 41 & 48 & 27 & 23 \\
RD & 3 & 9 & 18 & 25 & 7 & 36 & 18 & 15 & 17 & 8 & 14 & 11 \\
$\Sigma$ & 29 & 158 & 155 & 392 & 127 & 439 & 198 & 333 & 299 & 299 & 144 & 186 \\
\end{tabular}

$\mathrm{PD}=$ poultry dropping; $\mathrm{RPF}=$ ripped pawpaw fruit; $\mathrm{RBP}=$ ripped banana peel; $\mathrm{RBF}=$ ripped banana fruit; $\mathrm{TO}=$ Telferia occidentalis; $\mathrm{LM}=$ commercial layers mash; $\mathrm{RD} 10=10 \%$ rumen digesta diet; $\mathrm{RD}=\mathrm{rumen}$ digesta; A.A.= Achatina achatina; A.M.= Achachatina marginata .

wooden cage (one genotype/compartment). A one week pre-experimental period was observed during which the snails were given unlimited access to fresh quantities of the proposed feed materials each day. This was to condition the snails and enable them to develop post ingestive cues. The feeds were removed from the snails two nights to the start of the feeding trials to stimulate hunger, locomotory activity and feeding motivation (Chevalier et al., 2000; Scott et al., 2005).

During the experiment, the various feed materials were arranged side by side in the cages and the snails were arranged at the centre of the cage from where they were allowed to move to the feed of their choice. The feeds were arranged in a semi circle to shorten the distances between them. This was to enable each snail reach all the feeds in the shortest possible time. A. achatina and A. marginata snails cover a distance of about $28 \mathrm{~cm} / \mathrm{h}$ (range: $21.5-34.6 \mathrm{~cm}$, Ademolu et al., 2011) during the active period (nocturnal period). Therefore, the snails were allowed $60 \mathrm{~min}(1 \mathrm{~h})$ from the time of introduction of feed materials $(18: 30 \mathrm{~h})$ to sample and settle for the feed of their choice before recording was started. The positions

Table III. Distribution (number) of feeding snails by genotype (mean and SEM) to different feedstuffs. (Distribución (número) de caracoles por genotipo (media y EE) para diferentes alimentos).

\begin{tabular}{lccccccccr}
\hline Genotype & \multirow{2}{*}{ PD } & \multirow{2}{*}{ RPF } & RBP & RBF & TO & LM & RD10 & RD & SEM \\
\hline A. achatina & $4.36^{\mathrm{a}}$ & $1.31^{\mathrm{c}}$ & $0.95^{\mathrm{c}}$ & $1.31^{\mathrm{c}}$ & $2.95^{\mathrm{b}}$ & $4.12^{\mathrm{a}}$ & $3.64^{\mathrm{ab}}$ & $1.83^{\mathrm{c}}$ & 0.30 \\
A. marginata & $2.76^{\mathrm{d}}$ & $7.98^{\mathrm{b}}$ & $3.14^{\mathrm{d}}$ & $5.95^{\mathrm{c}}$ & $5.38^{\mathrm{c}}$ & $9.12^{\mathrm{a}}$ & $6.12^{\mathrm{c}}$ & $2.48^{\mathrm{d}}$ & 0.38
\end{tabular}

$\mathrm{PD}=$ poultry dropping; $\mathrm{RPF}=$ ripped pawpaw fruit; $\mathrm{RBP}=$ ripped banana peel; $\mathrm{RBF}=$ ripped banana fruit; $\mathrm{TO}=$ Telferia occidentalis; $\mathrm{LM}=$ commercial layers mash; $\mathrm{RD} 10=10 \%$ rumen digesta diet; $\mathrm{RD}=$ rumen digesta.

abcdmeans on the same row with different superscripts are significantly $(p<0.05)$ different. 


\section{FEEDING BEHAVIOUR OF TWO AFRICAN GIANT LAND SNAILS}



$\mathrm{PD}=$ poultry dropping; $\mathrm{RPF}=$ ripped pawpaw fruit; $\mathrm{RBP}=$ ripped banana peel; $\mathrm{RBF}=$ ripped banana fruit; $\mathrm{TO}=\mathrm{T}$. occidentalis; $\mathrm{LM}=$ layers mash; $\mathrm{RD} 10=10 \%$ rumen digesta diet; $\mathrm{RD}=$ rumen digesta Means with different letters are significantly different $(p<0.05)$.

Figure 1. Comparative distribution of snails to feed stuffs. The number of A. marginata snails significantly $(p<0.05)$ exceeded those of A. achatina snails for all feed types except $P D$ (A. achatina > A. marginata, $p<0.05)$ and $R D$ ( $p>0.05)$. (Distribución de los caracoles sobre los alimentos empleados. El número de $A$. marginata excedió $(p<0,05)$ del de $A$. achatina, para todos los tipos de alimentos salvo $(p<0,05)$ para PD y RD).

of the feeds were alternated daily to eliminate positional effect. For the duration of the experiment (7 days), the snails were fed only during the nocturnal period starting from 18:30 to $06: 00 \mathrm{~h}$ however, observation and recording was carried out hourly from 19:30 to $00: 30 \mathrm{~h}$ each day. Water was provided $a d$ libitum to all experimental units. The design and implementation of the study conformed to the relevant provisions of the Animal Use Act of the University of Nigeria, Nsukka.

\section{MeAsures and statistical anALYSIS}

The number of snails observed feeding on a feed stuff was recorded and used as a measure of feed preference (Negovetic and Jokela, 2000; Albuquerque et al., 2008). Snails found between feed stuffs were not included for either feeds. Snails not associated with any feed material were not included in the analysis. The distribution of snails to feeds was recorded over six (6) time periods of $60 \mathrm{~min}(1 \mathrm{~h})$ interval. Data collected were subjected to Analysis of Variance using the SPSS computer software (SPSS, 2007) and significantly different means were separated using Fisher's LSD. Comparison between snail species was done using independent t-test option in SPSS (2007).

\section{RESULTSANDDISCUSSION}

The percent and proximate compositions of the diet containing $10 \%$ rumen digester (RD10), as well as the proximate composition of rumen digesta (RD) are presented in table I while the cumulative number (sum for 7 days) of feeding snails of each species for different feed stuffs and at different time periods are presented in table II. The number of feeding A. marginata snails for the different feed stuffs and at the different time periods exceeded (numerically) those of $A$. achatina snails except for PD and RD at 23:30 h. This indicates that the A. marginata snails employed in the present study were more voracious foragers than their $A$. achatina counterparts.

The mean daily distribution of feeding

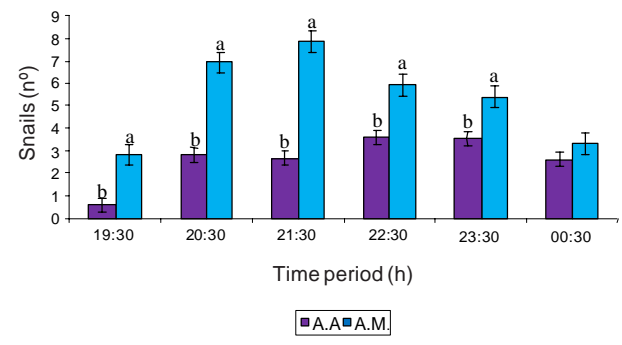

Means with different letters are significantly different $(p<0.05)$.

Figure 2. Comparative distribution offeeding snails according to time period. Observed number offeeding A. marginata snails were significantly $(p<0.05)$ higher than those of A. achatina snails at all time periods except at 00:30 h ( $p>0.05)$. (Distribución comparativa de la alimentación de los caracoles según el periodo de tiempo. Los números de $A$. marginata comiendo, fueron más altos $(p<0,05)$ que los de $A$. achatina en todos los periodos de tiempo salvo a $00: 30 h(p>0,05))$. 
OGBU, ANI AND EMEH

Table IV. Distribution (number) of feeding snails (mean and SEM) according to genotype and time period. (Distribución (número) de caracoles comiendo (media y $\mathrm{EE}$ ), según el genotipo y periodo de tiempo).

\begin{tabular}{lccccccr}
\hline Genotype & \multicolumn{7}{c}{ Time period (h) } \\
& $19: 30$ & $20: 30$ & $21: 30$ & $22: 30$ & $23: 30$ & $00: 30$ & SEM \\
\hline A. achatina & $0.57^{\mathrm{c}}$ & $2.79^{\mathrm{b}}$ & $2.67^{\mathrm{b}}$ & $3.59^{\mathrm{a}}$ & $3.54^{\mathrm{a}}$ & $2.61^{\mathrm{b}}$ & 0.26 \\
A. marginata & $2.82^{\mathrm{d}}$ & $6.91^{\mathrm{b}}$ & $7.84^{\mathrm{a}}$ & $5.93^{\mathrm{c}}$ & $5.38^{\mathrm{c}}$ & $3.32^{\mathrm{d}}$ & 0.33 \\
\hline
\end{tabular}

abcdmeans on the same row with different superscripts are significantly $(p<0.05)$ different.

snails to different feed stuffs for the two species are presented in table III while figure 1 compares the distribution of snails to different feed stuffs in the two species. A. achatina snails fed more on PD, LM and RD10 (4.36, 4.12 and 3.64 snails, respectively) compared to other feed stuffs while $A$. marginata snails preferred LM, RPF, RD10, $\mathrm{RBF}$, and TO $(9.12,7.98,6.12,5.95$, and 5.38 snails, respectively) compared to other feed stuffs (table III). These results indicate differences in the degree to which each of the feed stuffs was accepted probably on account of differences in their physical and chemical properties all of which influence the recognition and choice of food in animals (Iglesias and Castillejo, 1999; Chevalier et al., 2000; 2003). Iglesias and Castillejo (1999) studied the feeding pattern of Helix aspersa muller and reported that the snails did not feed at random and that nearly one half of feeding snails fed on Urtica dioica which presence also influenced the distribution of the snails. Compared to A. achatina, significantly ( $\mathrm{p}<0.05)$ higher numbers of $A$. marginata snails fed on all the feed stuffs except PD (A. achatina $>$ A. marginata, $\mathrm{p}<0.05)$, and RD ( $>0.05)$ (figure 1). This result reflect genetic differences in food preference and feeding propensity with $A$. marginata snails exhibiting higher propensity to feed, greater tolerance of feeding stuffs and/or a wider variety of feeding materials compared to A. achatina. Carefoot and Switzer-Dunlap (1989) reported stronger aversive tendencies to methionine in $A$. fulica compared to Cepaea nemoralis when both snails were fed diets having amino acid imbalance (excesses of methionine). Other studies that reported genotypic differences in feed preferences of land snails include ElDeep et al. (1996), Tadros et al. (2001), and Shahawy et al. (2008).

Table IV compares the effect of time period on the distribution of feeding snails of each species while figure 2 compares the number of the different snail species feeding at the various time periods. For A. achatina snails, the highest numbers of feeding snails

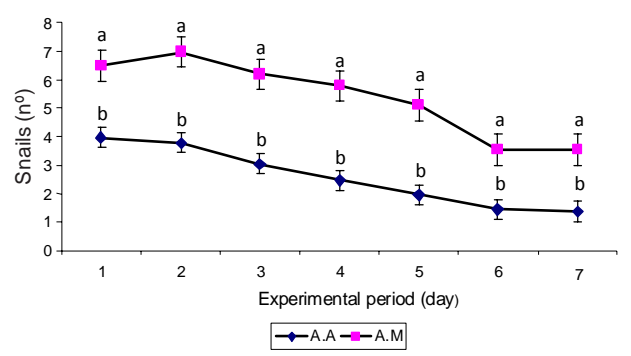

Means with different letters are significantly different $(p<0.05)$.

Figure 3. Temporary changes in the distribution of feeding snails (mean \pm SEM) over the experimental days. Feeding snails decreased with experimental days in both species and number offeeding A. marginata snails significantly $(p<0.05)$ surpassed those of A. achatina on each day. (Cambios con el tiempo en la distribución de los animales comiendo (media $\pm E E$ ). El número de caracoles comiendo disminuyó en las dos especies, el número de $A$. marginata superó $(\mathrm{p}<0,05)$ a $A$. achatina cada día). 
FEEDING BEHAVIOUR OF TWO AFRICAN GIANT LAND SNAILS

Table $\boldsymbol{V}$. Daily distribution (number) of feeding snails (mean and SEM) according to feed stuff and time period $(h)$. (Distribución (número) diaria de la alimentación de los caracoles (media y $\mathrm{EE})$, según el alimento y periodo de tiempo).

\begin{tabular}{|c|c|c|c|c|c|c|c|}
\hline & 19:30 & $20: 30$ & $21: 30$ & $22: 30$ & $23: 30$ & $00: 30$ & SEM \\
\hline \multicolumn{8}{|c|}{ A. achatina } \\
\hline PD & $1.29^{c}$ & $6.00^{\mathrm{a}}$ & $4.71^{\mathrm{a}}$ & $6.43^{a}$ & $3.86^{b}$ & $3.86^{b}$ & 0.74 \\
\hline RPF & 0.14 & 1.14 & 0.57 & 1.29 & 1.71 & 0.86 & 0.74 \\
\hline RBP & 0.14 & 1.71 & 0.86 & 1.29 & 2.57 & 1.29 & 0.74 \\
\hline RBF & 0.43 & 1.71 & 1.14 & 1.86 & 2.00 & 0.71 & 0.74 \\
\hline TO & $0.71^{c}$ & $2.43^{b c}$ & $2.14^{\mathrm{bc}}$ & $3.29^{b}$ & $5.29^{a}$ & $3.86^{a b}$ & 0.74 \\
\hline LM & $0.86^{c}$ & $4.86^{\mathrm{ab}}$ & $4.00^{\mathrm{b}}$ & $6.14^{a}$ & $4.57^{a b}$ & $4.29^{b}$ & 0.74 \\
\hline RD10 & $0.57^{c}$ & $1.86^{c}$ & $3.71^{b}$ & $5.86^{a}$ & $5.86^{a}$ & $4.00^{b}$ & 0.74 \\
\hline $\mathrm{RD}$ & $0.43^{c}$ & $2.57^{a}$ & $1.00^{\mathrm{ab}}$ & $2.57^{a}$ & $2.43^{\mathrm{a}}$ & $2.00^{\mathrm{ab}}$ & 0.74 \\
\hline \multicolumn{8}{|c|}{ A. marginata } \\
\hline PD & 1.43 & 3.71 & 3.43 & 2.43 & 3.57 & 2.00 & 0.94 \\
\hline RPF & $2.43^{d}$ & $11.00^{\mathrm{ab}}$ & $12.86^{a}$ & $9.43^{a}$ & $6.86^{c}$ & $4.29^{d}$ & 0.94 \\
\hline RBP & $1.71^{b}$ & $3.71^{\mathrm{ab}}$ & $4.29^{a}$ & $4.29^{a}$ & $2.71^{\mathrm{ab}}$ & $2.14^{\mathrm{ab}}$ & 0.94 \\
\hline RBF & $5.57^{b}$ & $7.86^{a}$ & $7.86^{\mathrm{a}}$ & $5.43^{b}$ & $6.43^{a b}$ & $2.57^{c}$ & 0.94 \\
\hline $\mathrm{TO}$ & $2.86^{c}$ & $7.57^{\mathrm{a}}$ & $5.43^{b}$ & $5.86^{\mathrm{ab}}$ & $5.57^{b}$ & $5.00^{\mathrm{bc}}$ & 0.94 \\
\hline LM & $3.71^{c}$ & $10.29^{b}$ & $15.00^{a}$ & $10.14^{b}$ & $9.86^{b}$ & $5.71^{c}$ & 0.94 \\
\hline RD10 & $2.57^{b}$ & $7.57^{a}$ & $8.71^{a}$ & $7.71^{a}$ & $6.86^{a}$ & $3.29^{b}$ & 0.94 \\
\hline $\mathrm{RD}$ & $1.29^{c}$ & $3.57^{\mathrm{ab}}$ & $5.14^{a}$ & $2.14^{b}$ & $1.14^{\mathrm{c}}$ & $1.57^{\mathrm{bc}}$ & 0.94 \\
\hline
\end{tabular}

$\mathrm{PD}=$ poultry dropping; $\mathrm{RPF}=$ ripped pawpaw fruit; $\mathrm{RBP}=$ ripped banana peel; $\mathrm{RBF}=$ ripped banana fruit; $\mathrm{TO}=$ Telferia occidentalis; $\mathrm{LM}=$ commercial layers mash; $\mathrm{RD} 10=10 \%$ rumen digesta diet; $\mathrm{RD}=$ rumen digesta.

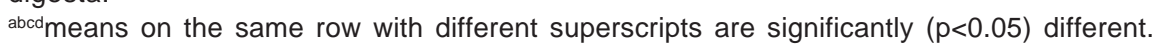

were observed at 22:30 and 23:30 h (3.59 and 3.54 snails, respectively) which represent the observed periods of peak feeding behaviour in this species while for $A$. marginata snails, it occurred at $21: 30 \mathrm{~h}$ (table IV). Ademolu et al. (2011) had reported that most feeding activity in the same snail species occurred between 21:00 and 02:00 h. The significantly higher numbers of feeding A. marginata snails (compared to $A$. achatina snails) at most time periods (figure 2) correspond to the greater distribution of this species to most of the feed stuffs. The highest differences occurred at the periods of highest feeding activity for $A$. marginata (i.e., 20:30 to 21:30 h) probably due to higher feeding propensity of this species.

There were significant $(\mathrm{p}<0.05)$ inte- raction effects of feed stuff and time period on the distribution of feeding snails of each species (table V). The highest numbers of $A$. achatina snails were observed feeding on PD between 20:30 and 22:30 h, TO at 23:30 and 00:30 h, LM and RD between 20:30 and 00:30 h, respectively and RD10 at 22:30 and 23:30 h. The number of $A$. achatina snails that fed on RPF, RBP and RBF did not vary significantly with time period. For $A$. marginata, except RBP which had the highest numbers of snails between 20:30 and $00: 30 \mathrm{~h}$ and PD for which the number of snails did not vary significantly with time period, the highest number of snails that fed on most of the other feed stuffs were observed between 20:30 and 23:30 h. For the two species, effect of feed stuff $x$ time period varied more distinctly for the most preferred 
OGBU, ANI AND EMEH

Table VI. Distribution (number) of feeding snails (mean and SEM) according to genotype, experimental days and feed stuff. (Distribución (número) de caracoles comiendo (media y EE) según el genotipo, día experimental y alimento).

\begin{tabular}{|c|c|c|c|c|c|c|c|}
\hline & \multicolumn{7}{|c|}{ Day } \\
\hline & 1 & 2 & 3 & 4 & 5 & 6 & 7 \\
\hline \multicolumn{8}{|l|}{ A. achatina } \\
\hline PD & 4.00 & 5.33 & 4.67 & 4.17 & 4.33 & 4.17 & 3.83 \\
\hline RPF & 2.17 & 1.00 & 1.83 & 1.00 & 0.33 & 0.33 & 0.00 \\
\hline RBP & 2.00 & 1.67 & 1.67 & 2.00 & 1.17 & 0.50 & 0.17 \\
\hline RBF & 2.67 & 2.33 & 2.50 & 0.83 & 0.33 & 0.17 & 0.33 \\
\hline TO & 3.00 & 3.83 & 4.50 & 4.33 & 2.67 & 1.33 & 1.00 \\
\hline LM & 6.50 & 6.50 & 3.00 & 3.50 & 3.33 & 2.67 & 3.33 \\
\hline RD10 & 6.00 & 5.50 & 3.83 & 2.67 & 3.17 & 2.17 & 2.17 \\
\hline $\mathrm{RD}$ & 5.33 & 3.83 & 2.33 & 1.00 & 0.33 & 0.00 & 0.00 \\
\hline SEM & 0.83 & 0.83 & 0.83 & 0.83 & 0.83 & 0.83 & 0.83 \\
\hline$\Sigma$ & 31.67 & 29.99 & 24.33 & 19.50 & 15.67 & 11.34 & 10.83 \\
\hline$\%$ of total snail & 52.78 & 50.00 & 40.55 & 32.50 & 26.10 & 18.90 & 18.05 \\
\hline \multicolumn{8}{|l|}{ A. marginata } \\
\hline PD & 3.00 & 3.67 & 3.17 & 3.00 & 2.17 & 2.33 & 2.00 \\
\hline RPF & 8.00 & 8.33 & 8.17 & 8.33 & 8.50 & 7.17 & 7.33 \\
\hline RBP & 4.00 & 4.17 & 3.33 & 3.00 & 3.67 & 1.67 & 2.17 \\
\hline RBF & 7.00 & 7.50 & 5.83 & 5.83 & 7.50 & 4.17 & 3.83 \\
\hline TO & 7.50 & 8.00 & 6.67 & 6.67 & 4.00 & 2.83 & 2.00 \\
\hline LM & 9.17 & 10.50 & 11.67 & 9.33 & 8.67 & 7.33 & 7.17 \\
\hline RD10 & 8.00 & 9.17 & 7.83 & 7.33 & 4.83 & 2.33 & 3.33 \\
\hline RD & 5.33 & 4.33 & 2.83 & 2.67 & 1.33 & 0.33 & 0.50 \\
\hline SEM & 1.24 & 1.24 & 1.24 & 1.24 & 1.24 & 1.24 & 1.24 \\
\hline$\Sigma$ & 52.00 & 55.67 & 49.5 & 46.16 & 40.67 & 28.16 & 28.33 \\
\hline$\%$ of total snail & 86.67 & 92.78 & 82.5 & 76.93 & 67.78 & 46.93 & 47.22 \\
\hline
\end{tabular}

$\mathrm{PD}=$ poultry dropping; $\mathrm{RPF}=$ ripped pawpaw fruit; $\mathrm{RBP}=$ ripped banana peel; $\mathrm{RBF}=$ ripped banana fruit; $\mathrm{TO}=$ Telferia occidentalis; $\mathrm{LM}=$ layers mash; $\mathrm{RD} 10=10 \%$ rumen digesta diet; $\mathrm{RD}=$ rumen digesta .

feed stuffs (PD, LM, RD10, and TO for A. achatina and LM, RPF, RD10, RBF, and TO for A. marginata). This could be related to the selective behaviour of animals when fed free choice food. Animals usually sample all feeds supplied before settling down with the most nutritive (preferred) ones with temporary switches among the preferred types.

The effects of experimental days on number of feeding snails of each species are presented in figure 3. There was a progressive reduction in the number of feeding snails with days of experiment. The number of feeding A. marginata and A. achatina snails stabilized at approximately 4 and 1 snail, respectively by D6. The highest numbers of feeding snails were recorded within the first two days of the experiment probably because the snails were starved for two nights before the trial. Thus the snails were motivated to search for food by hunger (Scott et al., 2005). The reduction in the number of feeding snails subsequently could therefore be due to lack of the desire for food in some of the snails that had eaten previously. Furthermore, snails differ in their propensity to feed and interindividual variation in feeding desire is common 


\section{FEEDING BEHAVIOUR OF TWO AFRICAN GIANT LAND SNAILS}

throughout the animal kingdom. In a study of interindividual variation in prey selection in the field, West (1986) reported that out of 128 marked Nucella emarginata, 104 snails were observed through two or more feeding attacks while 51 showed five or more sequential feeding bouts.

The mean number of snails that fed on each feed type and the cumulative for all feed types on the different days of the experiment are presented in table VI. There was no significant ( $p>0.05$ ) within feed stuff variation in number of feeding snails across the experimental days however, the number and percentage of snails that fed on each day decreased with experimental days after D1 in A. achatina and D2 in A. marginata. The number and percentage of feeding $A$. achatina snails decreased progressively from 31.67 snails or $52.78 \%$ on D1 to 10.83 snails or $18.05 \%$ on D7 while it varied from 52.0 snails or $86.67 \%$ on D1 to 28.33 snails or $47.22 \%$ on D7 for A. marginata. As much as $47.22 \%$ of A. achatina snails (compared to $13 \%$ of $A$. marginata snails) did not feed on $\mathrm{D} 1$. This result is surprising considering that the snails were starved two days to the commencement of the study and that snails were fed only during the nocturnal period. In the feed preference test by Chevalier et al. (2000) using H. aspersa, 6 snails (30\%) did not show any feeding activity. The decrease in percentage of feeding snails from D2 to D6 (mean: 10\%) was similar in the two species and the number of feeding snails appeared to stabilize by D6. The highly reduced feeding activity in A. achatina as obtained in the present study could be an adaptive mechanism in this species.

The daily trend in the number of snails that fed on three most appetent and inappetent feed stuffs is presented in figure 4 for the two species. The three most appetent feed stuffs for A. achatina (LM, RD10 and PD) achieved stable number of feeding snails by D4 of the experiment while for the most inappetent ones (RD, RPF, and $\mathrm{RBP}$ ), number of feeding snails continued on a downward trend to zero (or near zero) by D6 (RD) or D7 (RPF and RBP, respectively). The picture was generally the same for $A$. marginata except that the number of snails that fed on the inappetent feed materials did not decreased to zero by the end of the experiment. The observed pattern of snail distribution to the appetent and inappetent feed stuffs was in accord with the report by Chevalier et al. (2000). In their experiment with Lupinus albus, the authors reported that the bitter chemotype was rejected by $H$. aspersa after 4 days of the experiment in favour of the intermediate chemotype while the intermediate chemo-
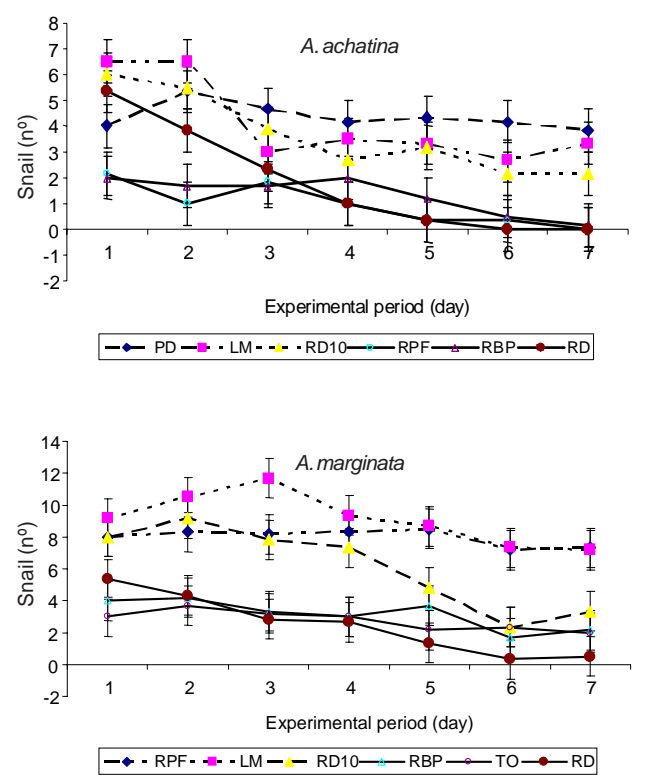

A. achatina. Most appetent: $\mathrm{PD}=$ poultry dropping; $\mathrm{LM}=$ layer mash $\mathrm{RD} 10=10 \%$ rumen digester diet. Most inappetent: $\mathrm{RPF}=$ ripped pawpaw fruit; $\mathrm{RBP}=$ ripped banana peel; $\mathrm{RD}=$ rumen digester. A. marginata. Most appetent: $\mathrm{RPF}=$ ripped pawpaw fruit; $\mathrm{LM}=$ layer mash; RD10 $=10 \%$ rumen digester diet. Most inappetent: $R B P=$ ripped banana peel; $\mathrm{TO}=T$. occidentalis; $\mathrm{RD}=$ rumen digester .

Figure 4. Evolution of daily distribution of feeding snails to three most appetent and inappetent feed stuffs. (Evolución de la distribución diaria de los caracoles comiendo sobre los tres alimentos más y menos apetecibles). 


\section{OGBU, ANI AND EMEH}


Figure 5. Evolution of hourly distribution of feeding snails. A definite pattern of peak feeding behaviour at 23:30 hoccurred on D5 and 7 in $\mathrm{A}$. achatina but at 21:30 hon all days in A. marginata. (Evolución de la distribución horaria de los caracoles comiendo. Se observa actividad máxima a las $23: 30 \mathrm{~h}$, los días 5 y 7 en A. achatina y a las $21: 30$, todos los días en $A$. marginata).

type was rejected in favour of the sweet chemotype after 6 days of the experiment. Our results indicate that with continuous presence of the appetent feed stuffs, consumption of the inappetent ones will eventually cease. The elongated consumption of inappetent feeds by A. marginata snails indicate that this species has greater tolerance for these feeds while the consis-

\section{REFERENCES}

Ademolu, K.O.; Jayeola, O.A.; Idowu, A.B. and Elemide, I.O. 2011. Circadian variation in locomotor and feeding periods of two land snail species. Arch Zootec, 60: 1323-1326.

Albuquerque, F.S.; Peso-Aguiar, M.C. and Assuncao-Albuquerque, M.J.T. 2008. Distribution, tent high number of snails associated with the most appetent feed stuffs indicate retention of feeding knowledge or memory in the two species (Watanabe et al., 2008; Ebenso and Adeyemo, 2011). The distinguishing features of the appetent and inappetent feeds could be in their attractiveness and/or palatability (Scott et al., 2005).

The distribution of feeding snails during different time periods on D1, D3, D5 and D7 of the experiment is presented in figure 5 for the two species. A definite pattern of peak feeding behaviour at 23:30 h occurred on D5 and 7 in A. achatina but at 20:30 and 21:30 $\mathrm{h}$ on all days in $A$. marginata. For $A$. achatina, the curve for D3 indicate an emerging pattern of peak feeding behaviour at specific time periods which became obvious on D5 and D7, respectively. Feeding behaviour peaked earlier at 20:30 and 21:30 $\mathrm{h}$ in A. marginata and this reflect early nocturnal feeding bouts in this species compared to A. achatina.

\section{CONCLUSION}

The snail species showed the ability to choose and to recognize their preferred feed stuffs subsequently. The three most preferred feed stuffs were LM, RD10 and PD for A. achatina and LM, RPF and RD10 for A. marginata. Furthermore, the snails showed species related pattern of feeding behaviour which peaked between 22:30 and 23:30 $\mathrm{h}$ in A. achatina and 20:30 and $21: 30 \mathrm{~h}$ in A. marginata. These factors should inform the design and implementation of an optimal feeding regimen for farmed A. achatina and A. marginata snails.

feeding behaviour and control strategies of the exotic land snail Achatina fulica (Gastropoda: Pulmonata) in the northeast of Brazil. Braz $J$ Biol, 68: 837-842.

Carefoot, T.H. and Switzer-Dunlap, M. 1989. Effect of amino acid imbalance in artificial diets on food 


\section{FEEDING BEHAVIOUR OF TWO AFRICAN GIANT LAND SNAILS}

choice and feeding rates in two species of terrestrial snails, Cepaea nemoralis and $A$. fulica. J Mollus Stud, 55: 323-328. doi: 10.1093/ mollus/55.3.323.

Chevalier, L.; Desbuquois, C.; Papineau, J. and Charrier, M. 2000. Influence of the quinolizidine alkaloid content of Lupinus albus (Fabaceae) on the feeding choice of Helix aspersa (Gastropoda: Pulmonata). J Mollus Stud, 66:61 68

Chevalier, L.; Le Coz-Bouhnik, M. and Charrier, M. 2003. Influence of inorganic compounds on food selection by the brown garden snail Cornus aspersum (muller)(Gastropoda: Pulmonata). Malacologia, 45: 125-132.

Ebenso, I.E. and Adeyemo, G.O. 2011. Foraging behaviour responses in African Giant Land snail Achatina achatina. Ethiopian J Environ Stud Manage, 4: 46-49.

El-Deep, H.I.; El-Ghamry, E.M.; El-Hwashy, N. and Essa, N. 1996. Relative aboundance of some land snails in certain governorate of Egypt. $J$ Agric Sci Mansoura Univ, 21: 2977-2983.

Gillete, R.; Huang, R-C.; Hatcher, N. and Moroz, L.L. 2000. Cost-benefit analysis potential in feeding behaviour of a predatory snail by integration of hunger, taste, and pain. PNAS, 97: 3585-3590.

Iglesias, J. and Castillejo, J. 1999. Field observations on feeding of the snail Helix aspersa muller. J Mollus Stud, 65: 411-423.

Kimberly, D.A. and Salice, C.J. 2012. Dietary acclimation affects dietary selection in the freshwater snail, Planorbella trivolvis. J Mollus Stud. Doi: 10-1093/mollus/eys013.

Negovetic, S. and Jokela, J. 2000. Food choice behaviour may promote habitat specificity in mixed populations of clonal and sexual Pota- mopyrgus antipodarum. Anim Behav, 60: 435441.

Ogbu, C.C. and Ugwu, S.O.C. 2011. Evaluation of pre-mating reproductive isolation in Archachatina marginata from three populations in the humid tropics. Afr J Biotechnol, 10: 1466914677.

Provenza, F.D. 1995. Postingestive feed back as an elementary determinant of food preference and intake in ruminants. $J$ Range Manage, 48: 2-17.

Scott, J.D.; Dawson-Scully, K. and Sokolowski, M.B. 2005. The neurogenetics and evolution of food-related behaviour. Trends in Neuroscience, 28: 644-652.

Shahawy, W.A.; Hendawy, A.S.; Abada, A.E. and Kasem, A.A. 2008. Land snails infesting rice plants and their accompanied parasitoids and predators at Kafr El-Sheikh governorate, Egypt. Egypt J Agric Res, 86: 971-980.

SPSS. 2007. Statistical Package for Social Sciences version 17.0. SPSS Inc. Chicago. U.S.A.

Tadros, A.W.; Nakhla, J.M. and Rizk, M.A. 2001. The relative susceptibility of fruit tree species to land snail infestation as indicated by cells in their excrement. Egypt J Agric Res, 79: 57-68.

Ugwu, S.O.C.; Ogbu, C.C. and Amaechi, C.C. 2011. Effect of soil type and soil depth on the reproductive performance of two species of giant African land snails in the humid tropics. Int J Sci Nature, 2: 176-182.

Watanabe, S.; Kirino, Y. and Gelperin, A. 2008. Neural and molecular mechanisms of microcognition in Limax. Learning \& Memory, 15: 633-642.

West, L. 1986. Interindividual variation in prey selection by the snail Nucella (= Thias) emarginata. Ecology, 67: 798-809. 